\title{
PREVENTIVE PROCEEDINGS IN THE VISION OF THE CODE ON PREVENTINVE PROCEEDINGS OF INSOLVENCY AND OF INSOLVENCY - A FIRST STEP FOR THE HARMONIZATION OF THE EU MEMBER STATE'S LEGISLATIONS IN THIS AREA
}

\author{
E.N. Vâlcu, L. Olah
}

\section{Elise-Nicoleta Vâlcu}

Faculty of Law and Administrative Sciences, University of Piteşti, Piteşti, Romania

* Correspondence: Elise-Nicoleta Vâlcu, University of Piteşti, Faculty of Law and

Administrative Sciences, 71 Republicii Blvd., Piteşti, Argeş, 110014

E-mail: elisevalcu@yahoo.com

\section{Lavinia Olah}

Faculty of Law and Administrative Sciences, University of Piteşti, Piteşti, Romania *Correspondence: Lavinia Olah, University of Piteşti, Faculty of Law and Administrative Sciences, 71 Republicii Blvd., Piteşti, Argeş, 110014

E-mail: lavinia olah@yahoo.com

\begin{abstract}
In order to improve and accelerate the insolvency with cross border implications, the Council has adopted the Council Regulation (EC) No 1346/2000 of 29 May 2000 on insolvency proceedings establishing the common norms on the jurisdiction, recognition and applicable law in this area, European norm which does not harmonizes the national material law systems in the area of insolvency, thus it can be identified significant differences at a national legislative level regarding the insolvency in relation to fundamental considerations of politics, structure and content, in other words, there are not unique insolvency proceedings, with applicability throughout the European union. Nevertheless we consider that a first step in the achievement of a legislative uniformity was already taken, at least regarding the unity regulation of certain preventive proceedings which will allow the avoidance of insolvency of the debtor, mentioning in this respect Law No 381/2009 on the preventive concordat and the ad-hoc mandate, whose provisions are taken from the new code on the preventive proceedings of insolvency and of insolvency, code which eases the direct application of the Council Regulation (EC) No 1346/2000.
\end{abstract}

Keywords: financial difficulty, preventive concordat, ad-hoc mandate, recovery plan, proceeding

\section{Introduction}

The preventive proceedings stated by the Law $381 / 2009^{1}$ and inserted in the new code on the preventive proceedings of insolvency and of insolvency ${ }^{2}$ have as purpose the

\footnotetext{
${ }^{1}$ Official Gazette No 870/14 October 2009.

${ }^{2}$ With the entrance into force of the new code the followings normative documents shall be abrogated: Law No $85 / 2006$ on insolvency procedure, Law No 381/2009 on the on the preventive concordat and the ad-hoc mandate, Government Ordinance No 10/2004 on the bankruptcy of credit institutions, Chapter 3 and 4 "The procedure of insolvency for insurance undertakings" of the Law No 503/2004 on the financial recovery and bankruptcy of insurance undertakings, Law No 637/2002 regulating the international Private law relations concerning insolvency, published in the Official Gazette No 931/19 December 2002, as further amended and supplemented. Also, the Project of Law reiterates the actual legal provisions of transposing the EU Directive in the area of bankruptcy for credit institutions: Directive No 2001/24/EC of the European Parliament and of the Council of 4
} 
safeguarding the debtor found in a financial difficulty, and as main purpose the continuance of his activity, but also the maintenance of the creditors' debts on the debtor, by amicable settlements of renegotiating the debts or their conditions. The settlements between the debtor and creditor are accomplished by the procedure of the ad-hoc mandate $e^{3}$ or by the conclusion of a preventive concordat.

According to Art 4 of the project-code on the preventive proceedings of insolvency and of insolvency, the preventive proceedings are based on the principle of granting an opportunity for the honest debtors to an efficient and effective recovery of their business, either by the preventive proceedings of insolvency, or by the judicial reorganization procedure, namely favoring, in the procedure of pre-insolvency, the amicable negotiation/renegotiation of the debts and a preventive concordat.

\section{Preventive concordat - a preventive procedure applicable for the debtors found in difficulty}

a) Definition and features of the preventive concordat

The preventive concordat is a contract concluded between, on the one hand, the debtor found in a financial difficulty and on the other hand the creditors having at least two thirds of the value of the debts accepted and undisputed, on the other hand, by which the debtor proposes a plan for the recovery and achievements of the debts to this creditors, and the creditors agree to support the efforts of the debtor to overcome the difficulty in which he is in (Art 3 Let d)) of the Law No 381/2009, as well Art 5 Point 17 of the code of insolvency.

The features of the preventive concordat are:

i) The preventive concordat is the contract concluded between the debtor found in difficulty and his creditors. The law considers only the creditors who have at least two thirds of the value of the debts accepted and undisputed of the debtor.

ii) The preventive concordat states a deal on the financial recovery plan of the debtor's business and for covering the debts, elaborated by the debtor with a conciliator.

iii) The object of the preventive concordat is the financial recovery plan for the debtor's business and for covering the debts, elaborated by the debtor with a conciliator.

iv) The preventive concordat is established by the court.

b) The participants in the procedure of the preventive concordat are: the debtor

found in difficulty, the syndic judge, the conciliator and the creditors, namely the creditor's assembly.

The debtor - the beneficiary of the procedure. As the beneficiary of the procedure, every debtor may appeal the procedure of the preventive concordat, running a business found in a financial difficulty, without being in insolvency ${ }^{4}$.

April 200Ion the reorganization and winding up of credit institutions, published in the Official Journal of the European Communities L 125/5 May 2001.

3 The ad-hoc mandate is a confidential procedure, triggered by the request of the debtor, by which an ad-hoc representative renegotiates with the creditors with the purpose of reaching an agreement between one or more creditors and the debtor, in order to overcome the difficulty in which he is found (Art. 3 Let c) of the Law No 381/2009, as well as Art. 5 Point 34 of the Code of insolvency. The representative may propose deletions, reschedules or partial reductions of debts, the continuation or termination of contracts under execution, cutbacks, as well as any other measures considered to be necessary for the object of the mandate. According to Art. 13 Para. 2 of the new code, the object of the ad-hoc mandate must be achieved within 90 days from the appointment of the ad-hoc mandate.

${ }^{4}$ Art. 13 Let a)-f) of the Law No 381/2009, namely Art. 16 of the new code of insolvency states certain debtors for who is forbidden the procedure of preventive concordat. Specifically, it does enjoy the access to this procedure the debtor against whom was issued a definitive and irrevocable decision of conviction for economic offences or the procedure of insolvency was opened 5 years prior the offer for preventive concordat. Also, the debtor cannot access the procedure of concordat, if with 3 years prior the offer for preventive concordat, has been the beneficiary of another preventive concordat, or if the debtor and/or the shareholders/silent partners or his administrators were convicted in the past 5 years prior to the opening of the preventive concordat, for the 
The syndic judge. In the procedure of preventive concordat, the syndic judge has, according to the analyzed text, the following attributions:

i) Appoints the provisional conciliator;

ii) Ascertains, at the request of the conciliator, the preventive concordat, as well as to the request of a creditor not-signatory of the concordat, the fulfillment of the conditions required for his enlistment on the list of the creditors who have joined the preventive concordat;

iii) Provisionally suspends the enforcement procedures against the debtor based on the project of preventive concordat;

iv) Trials the actions for nullity or resolution of the preventive concordat.

The requests regarding the preventive concordat are trialed in the council chamber, with emergency and priority. Regarding the decisions stated by the syndic judge these are definitive and enforceable, being subjected to the appeal, without being suspended from enforcement ${ }^{5}$.

The conciliator. The procedure of the preventive concordat involves a conciliator who can be an insolvency practitioner ${ }^{6}$, whose honorary is a fixed amount, a monthly remuneration or an honorary for success established by the preventive concordat and supported by the debtor.

According to the $\mathrm{law}^{7}$, the conciliator or the concordat administrator has the following attributions:

i) Elaborates the list of the contestant and concordat creditors;

ii) Elaborates, with the debtor, the offer for concordat with its elements, namely the project for a preventive concordat and the recovery plan;

iii) Makes the necessary arrangements for the amicable resolution of any dispute between the debtor and creditors, or between the creditors;

iv)Requests to the syndic judge the establishment and/or, where appropriate, the homologation of the preventive concordat;

v) Supervises the fulfillment of the obligations assumed by the debtor in the preventive concordat;

vi) Elaborates and submits to the concordat creditors' assembly monthly or trimestral reports regarding his and the debtor's activities;

vii) Convokes the reunion of the concordat creditors;

viii) Asks the court to conclude the procedure of the preventive concordat;

ix) Fulfills any other attributions stated by the present chapter, by the preventive concordat or by the syndic judge.

The assembly of the concordat creditors. The creditors participating in the procedure of the preventive concordat form the assembly of the concordat creditors.

According to Art 18 of the Law No 381/2009, namely Art 21 of the new code of insolvency, the assembly of the concordat creditors has the following attributions:

a) Approves the reports from the conciliator on the activity of the debtor and the fulfillment of the obligations assumed by the preventive concordat;

b) Appoints the creditors' representative;

c) Is the initiator of the action for the resolution of the admission in composition with creditors.

offences stated by the law, or if the members of the management/supervision organs of the debtor were held liable according to the Law No 85/2006 on the procedure of insolvency. Not ultimately, the debtor does not have access to the procedure of preventive concordat if his tax offence record according to the Government Decision No 75/2001 on the organization of the tax offence records.

${ }^{5}$ Art. 18 of the new code of insolvency.

${ }^{6}$ Authorized in the conditions of G.D No 86/2006 on insolvency practitioners.

${ }^{7}$ Art. 16 of the Law No 381/2009, namely Art. 19 of the new code of insolvency. 
We notice that the code of insolvency no longer states the obligation of the creditors' assembly to modify, with the participation of the debtor, the conciliator's honorary.

During the procedure of the preventive concordat, the assembly of creditors can be convoked by the conciliator, ex officio or at the request of the creditors representing $10 \%$ of the total amount of the debts.

\section{c) Opening the procedure and the offer for a preventive concordat}

According to Art 20 of the Law No 381/2009, namely Art 23 of the code on insolvency, any debtor who is a legal person found in financial difficulty, may submit to the court a request to open the procedure of the preventive concordat by which he proposes for a provisional conciliator, from the insolvency practitioners authorized by the law, who will be appointed by the syndic judge, by an irrevocable agreement.

The offer for a preventive concordat. According to the law, within 30 days from his appointment, the conciliator and the debtor shall elaborate the list of creditors and the offer for a preventive concordat.

The offer for a preventive concordat shall comprise the project of the preventive concordat and the recovery plan ${ }^{8}$.

1. The project for a preventive concordat - represents the card of the debtor which must present the detailed analytical situation of the actives and passives owned by the debtor, certified by a chartered management accountant or, where appropriate, audited by an authorized auditor; the circumstances of the financial difficulty situation and the measures adopted by the debtor to overcome it; the financial evolution for the following 24 months, to which is annexed the declaration on the financial difficulty status containing also the list of known creditors of the debtor. We note that the code of insolvency is modified in relation to the law that is about to abrogate, the latter one stating a term of 6 months for which the debtor was compelled to elaborate a projection of his financial evolution. Using the project for a preventive concordat the debtors proposes the confirmation of the provisional conciliator.

2. The recovery plan states measures such as: reorganization of the debtor's activity (the restructuraţi on of the debtor's management, the modification of the functional structure, cutbacks etc.); means to overcome the financial difficulty situation (capital increment); issuance of bonds, bank loans, opening or closing branches or working points, selling actives, establishment of guarantees etc.; the percentage of satisfaction of the creditors' claims, with the possibility to ask for postpones or reschedules for the payment of the debts, total or partial erase of certain debts or only of the interests or delay penalties, compensations, novation; the deadline for satisfying the debts by the concordat, which can be of maximum 18 months from the conclusion of the preventive concordat. The version proposed by the new code state for the latter point above mentioned a term of 24 months from the moment of ascertain or homologation by an enforcement decision?

The conciliator presents to the creditors the offer for a preventive concordat and is attached to the case file.

d) Conclusion, approval, ascertain and homologation of the preventive concordat The conclusion of the preventive concordat is achieved as a result of the negotiations between the debtor and creditors regarding the offer for a preventive concordat within collective or individual sessions in the presence of the conciliator, with a duration which cannot exceed 30 calendar days. The new code states substantial modifications regarding the limit for the negotiations, namely 60 days ${ }^{10}$.

\footnotetext{
${ }^{8}$ Art. 21 of the Law No 381/2009 and Art. 23 Para 6 of the code on insolvency.

${ }^{9}$ See in this regard Art. 24 Para 2 of the code on insolvency.

${ }^{10}$ See Art. 26 Para 3 of the code on insolvency.
} 
e) Approving the preventive concordat by the creditors. The offer for a preventive concordat and any amendments resulted after the negotiations are subjected to the creditors' vote $^{11}$.

The preventive concordat is considered to be approved by the creditors if it meets the votes of the creditors representing two thirds of the value of accepted and undisputed debts. If the majority stated by the law is not met, the debtor has the right that after 30 days to make a new offer for a preventive concordat.

The ascertaining of the preventive concordat by the syndic judge $e^{12}$ is made at the request of the conciliator, by a decision adopted in the council chamber, with emergency and priority, after hearing the concordat administrator.

The preventive concordat, approved by the creditors and ascertained by the syndic judge is communicated to the creditors by the concordat administrator and registered in the trade register.

The ascertaining of the preventive concordat has as effects the rightful suspension of the individual pursuits performed by the creditors against their debtors and the beginning of the prescription of the right to ask for the enforcement of the debts against the debtor.

The homologation of the preventive concordat by the syndic judge is made at the request of the concordat administrator, with the purpose of insuring the opposability of the preventive concordat to the non-signatory creditors, including the unknown or contested creditors. In order to state the homologation, the syndic judge shall verify the cumulative fulfillment of the following conditions:

i) The value of the debts contested and/or found in litigation must not exceed $20 \%$ of the statement of affairs;

ii) The preventive concordat was approved by the creditors representing at least $80 \%$ of the total amount of the debts;

By a decision homologating the preventive concordat, the syndic judge suspends all procedures of enforcement against the debtor, being able to ask the non-signatory creditors for a term of maximum 18 months to postpone the deadline of their claims. During this period, shall not be imposed any interests, penalties or other expenses added to the debts.

Regarding the budgetary creditors, the law states that the opposability of the preventive concordat is conditioned by the compliance with the legal provisions regarding the state aid and its approval by the inter-ministerial commission.

\section{e) Conclusion of the preventive concordat}

The preventive concordat is concluded with the successful closure of the procedure, the impossibility of concluding a preventive concordat or, where appropriate, the annulment of the contract or the termination of the preventive concordat.

Art 34 of the Law No 381/2009, namely Art 102 of the code on insolvency, states that once the objectives established by the concordat were fulfilled, we are in the situation of the successful closure of the procedure, the syndic judge stating a decision ascertaining the achievement of the preventive concordat's objective.

Also, the procedure of the preventive concordat shall be closed if during its performance, but before the expiration of the deadline established for the procedure, the concordat administrator appreciates as impossible the achievement of the preventive concordat's objectives, for reasons which cannot be imputed to the debtor ${ }^{13}$, the latter one

\footnotetext{
${ }^{11}$ Art. 24 of the Law No 381/2009, namely Art. 27 Para 2 of the code on insolvency. In principle, the creditors vote by mail. They must communicate their vote to the debtor within 30 calendar days from the moment they received the offer for a preventive concordat. The unconditioned favorable vote for the preventive concordat has the value of the acceptation for the concordat. Any conditioning of the vote is considered a negative vote.

${ }^{12}$ Art. 26 of the Law No 381/2009, namely Art. 28 of the code on insolvency.

${ }^{13}$ See in this regard Art. 34 Para 2 of the Law 381/2009 and Art. 103 of the code on insolvency.
} 
being able to ask the syndic judge to state a decision ascertaining the failure of the preventive concordat and the conclusion of the procedure.

The annulment of the preventive concordat. The creditors who voted against the preventive concordat may request the annulment of the contract within 15 days from the registration of the concordat in the trade register.

If are invoked the reasons for full invalidity, the new code on insolvency states different than the old law, so if Art 32 of the Law No 381/2009 states that the right to invoke the nullity is imprescriptible and belongs to every interested person, the code states that when the reasons for full invalidity are invoked, the right to ask for a ruling of invalidity shall be prescribed within 6 months from the registration of the concordat in the register where the debtor is mentioned and belongs to every interested person.

The request regarding the termination of the preventive concordat shall be made by the concordat creditors' assembly if it is ascertained the serious breach by the debtor of the obligations assumed in the preventive concordat, namely favoring one or more creditors at the expenses of the others, hiding or externalizing assets during the preventive concordat, performing payments without a consideration or in ruinous conditions etc. ${ }^{14}$.

\section{Conclusions}

We consider that if in this moment the preventive procedures are stated differently by a special norm in relation to the procedure of insolvency, the code on the procedures of preventing the insolvency and on insolvency has the credit to propose an integrative vision, including in a single body the general legislation applicable to all business operators, the legislation in the area of preventing the insolvency, namely the ad-hoc mandate and the preventive concordat, and the special legislation, applicable for credit institutions and insurance undertakings, stating the insolvency for groups of societies, as well as rules on the cross border insolvency, covering the requirements for the legislative unification under the Regulation (EC) No 1346/2000 of 29 May 2010.

\section{Bibliography}

Law No 381/2009 on the preventive concordat and the ad-hoc mandate;

Regulation (EC) No 1346/2000 of 29 May 2000 on insolvency proceedings, published in the Official Journal of the European Union No L 160 of 30 June 2006;

Project for the Law on the procedures of preventing the insolvency and on insolvency.

\footnotetext{
${ }^{14}$ See in this regard Art. 98 of the code on insolvency.
} 